\title{
Intersectionality of Gender and Religious Politics in the Humanitarian Discourse of Ayat-Ayat Cinta Film
}

\author{
Sulkhan Chakim ${ }^{1 *}$, Nawawi ${ }^{1}$, Uus Uswatussolikah ${ }^{1}$, Moh Roqib $^{2}$ \\ ${ }^{1}$ Department of Islamic communication \& Broadcasting, IAIN Purwokerto, Purwokerto, Indonesia. \\ ${ }^{2}$ Department of Arabic Language, IAIN Purwokerto, Purwokerto, Indonesia. \\ *Corresponding author. Email: sulkhan@iainpurwokerto.ac.id
}

\begin{abstract}
Tension can lead to violence, competition and even hostility taking place at the intersection of power relations in the domestic and public sphere into the practice of domination and subordination simultaneously. This paper questions the resistance of religious and political gender relations in the relationship between Islam, Judaism, and Catholicism in Ayat-Ayat Cinta film (AAC). This research is a qualitative study that illustrates the crossing and resistance relations of religious adherents in the discourse of humanity. The research method is used in this study is Sara Mills's approach is more looking at how actors' positions are displayed in the text. The results of his research are the violence in interfaith relations caused by the construction of adherents of religion both produced through individuals and different social structures in the fight for humanity. The conclusion can be explained that the relationship between adherents of different religions, especially followers of Islam as a minority always gets pressure in the form of; swear, poor image, stupid, donkey, savage, and terrorist. Meanwhile, on the other hand, Muslims are constructed as tolerant, polite, friendly, and helpful.
\end{abstract}

Keywords: intersectional, gender, religious politics, humanity, Ayat-Ayat Cinta Film

\section{INTRODUCTION}

In the era of disruption, religious pluralism became the most important and hotly debated discourse among Muslims. The Organization of Islamic Conference (OIC Summit) Summit in Dakar, Senegal, 13-14 March 2008 also made pluralism an important issue. The theme is an effort to eliminate the growing fear of Islam. Time Magazine has uploaded five challenges facing the Jokowi government; political clutter, economic slowdown, religious extremism, dirty bureaucracy and racism [1]. Two of the five challenges of the Time Magazine version namely religious extremism and racism are issues of pluralism. These two challenges are constructed by the public; both religious extremism and racial and gender sentiments.

Media construction is a reflection of the reality of a society where democracy is strong, mature, behaves and acts that are constructed in different forms. Vice versa, the media is often an instrument of the interests of the authorities or dominant parties who are not democratic. The era of democracy which requires freedom of the press is not merely positioning the media as a passive party representing the face of society. It is a medium, space, which is able to manipulate the representation of society to become more empowered or vice versa. In that context, the reality is built through the networks produced by messages [2]. The message is a contested concept and mystery [3] can also have negative and positive effects [4], such as the role of providing education, empowerment, entertainment, and advocacy to interested parties.

The film is one of the most popular mass media by the public. One of the religious films that once aroused optimism was the Ayat-Ayat Cinta film (1) and (2). This article examines cross-cutting of the religious and gender relations which had been constructed by the Ayat-Ayat Cinta film.

Social relations in the public are free from a dynamicinteractional relationship that needs each other, and even give birth to new problems that intersect, marginalize, exploit, and even practice domination. Various intersections of social inequality as a matrix of dominance. Way of thinking is one of the factors influencing oppression or domination caused by social differences [5]. The construction of differences in opposition dichotomy is difference rather than similarity [6].

Intersectionality is characterized as manifested similarly to religion. For example, public intellectual Andrew Sullivan argues that intersectionality manifests itself "almost as a religion. This places the classical orthodoxy through which all human experience is explained - and through which all speeches must be filtered. An understanding of original sin is the power of some identity groups over others. To overcome this sin or error, it is necessary to first confess, that is, "check the privilege of the doer", in a way that makes this sin unwavering [7] It always in process, always contested, always an accomplishment of practice [8]. Wisse condemned "Groupthink" at Harvard and defended Peretz, saying that "to hope that Muslims will condemn violence in their midst is not bigotry but freedom"[9]. Wisse has been criticized for writing that "Palestinian Arabs are people who produce and shed blood and advertise their suffering"[10]. This issue is propaganda that can lead to negative stereotypes and one party is in a subordinate position and the other party is dominant, or deliberately weakened by the ruling party [11]. 
Inequality of subject experience in a society is often organized and even maintained through the interrelation of several domains, according to Collins, (1) that the structural domain consists of several institutional structures, such as government, legal systems, various economic traditions, and educational systems; (2) the disciplinary domain which includes ideas and practices that characterize and maintain bureaucratic hierarchy; (3) the hegemony domain includes the images, symbols, ideas, ideologies that make up social awareness, (4) the interpersonal domain includes patterns of interaction between individuals and some groups [12],[13]. In various findings of the study of cases of inter and interfaith conflict occurring in Indonesia today is motivated by various factors, namely: ideology, politics, economy politics, and politics. For example, many researchers believe that the Sunni and Shi'a conflict in Madura is a conflict caused by ideological interests. In contrast to Masdar Helmy's research findings, that the Sunni and Shi'a conflict in Madura is not only caused by ideological or theological interests but for Masdar, both conflicts caused by political-economic interests are the main factors [14]. In addition, many educated or scholars in Indonesia enter into many radical groups, both social-religious organizations and political parties at various levels [15].

Some researchers are the social reality of Indonesian society which influences the construction of various media about the relations of followers of different religions. Furthermore, this study questions how the construction of violence produced by the relations between religious adherents in the film Ayat-Ayat Cinta (2)? And how the power relations of followers of different religions give birth to each other dominant and subordinate at the same time constructed in the Ayat-Ayat Cinta film.

\section{RESEARCH METHOD}

This research is qualitative in nature which aims to provide a way to describe reality, explain the processes that occur in it, and explain the various contexts behind it. One of research methods used in studies is Roland Barthes's semiotic analysis. He has introduced the idea of the text as an open disseminator of meaning by understanding all texts constructed by signs in a social context [16]. This analysis, the ideology, and power are hidden behind the text can be revealed through the language.

The research method is used in this study is Sara Mills's approach is more looking at how actors ' positions are displayed in the text. These positions in the sense of who is the subject of suffering will determine how the structure of the text and how it is treated in the text as a whole. In addition to the positions of actors in the text, Sara Mills also focuses on how readers and authors are displayed in the text [22].

\section{RESULTS AND DISCUSSION}

The film Ayat-Ayat Cinta (2) directed by Guntur Soeharjdanto as a continuation of the novel Ayat-Ayat Cinta (1) by Habiburraman El Shairazy was booming in the first round of about 3.5 million viewers and was loved by many Indonesians at that time. Whereas the Ayat-Ayat Cinta film (2) was screened in 2018, the response of the people was not as excited as the first round. Nevertheless, both novels and films are not free from criticism by writers and experts in the world of film. The Ayat-Ayat Cinta film (2) has more nuances of religious messages in the storyline and places aspects of religious relations in social life. Islam as a religion and as a way of looking at the lives of its adherents are often misunderstood by its own adherents and even other parties outside of Islam.

The relation of religious adherents in the film Ayat-Ayat Cinta is framed through the relations of Islam, Catholicism, and Judaism. Fahri as the main actor lives alone in Edinburg along with Hulusi (assistant) and Misbah (friend). Fahri lost Aisha (wife) when Aisha volunteered in the Gaza strip. Fahri in his social life is often confronted with issues of neighbors who are diverse in their beliefs and at the same time suspicious and even labeled negative as terrorists to Muslims and even to Fahri.

Catarina is a Jewish grandmother having problems with her stepson (Baruch); caused by eviction and being dragged to the ground in the yard, and even the house as an asset of Catarina was sold by her. At that time, Fahri heard the screams of Catarina's grandmother, then he approached her and tried to intervene while helping Catarina's grandmother. His stepdaughter instead rebukes and suspects Fahri as a terrorist and is considered "heroine" but often acts hypocritically in front of the crowd. Furthermore, the house sold by her stepdaughter has been bought back for Catarina's grandmother, while the grandmother lives together in one house with Fahri and her friends, without having to influence her diversity.

One day Fahri was invited to a debate competition at Edinburgh University where he taught. The debate begins, Fahri opposes Huntington's theory which states that the various dominance of conflicts occurs in global politics caused by the clash of different civilizations [17]. Whereas Sheikh Nursi [18] emphasizes peace and progress in the world life is humanity, so it must be built with love, not enmity, and even that hostility must be a common enemy. However, the debate has become a coachman debate in which Fahri is positioned in the forum as a savage and inhuman terrorist accomplice, Fahri's position in the debate forum is cornered into a coachman debate. Catarina's grandmother came, emphasizing that Fahri was not only limited to discourse, in fact, he had done it in a way to protect and help despite different beliefs. His assertion is that I swear by Moses, that "Fahri is a good person and a helpful Angel". Fahri has been helping and protecting me, which his stepchild should have done. At the end of the debate, with the testimony of Catarina's grandmother in the midst of the debate, Fahri received support from the visitors and was congratulated by the students. Even so, Fahri was pressured and even threatened with dismissal as a lecturer at Edinburgh University because, on charges of aiding terrorists, he moved and became a permanent lecturer at Oxford University. 


\subsection{Structural domain}

The setting of the Ayat-Ayat Cinta film (2) in London is a royal state and has a liberal system of government, namely a parliamentary system. Meanwhile, the education system becomes the center of higher education and world research. In this film, the University of Edinburgh is an educational institution that influences interfaith power relations. Fahri as a lecturer in Islamic studies in his tutorial discusses the political position of women, which most students assume, that women of Islam are in a subordinate position and in social positions that are not pleasing to women, such as being confined, other groups, and not independent. Besides, in the film Ayat-Ayat Cinta, one of the female students (Hulya) tried to give an idea about the extent to which Fahri allowed his students to argue about the position of women in Islam, is an attitude of respect for Muslim women. Interaction of messages about "the position of Muslim women" is a form of contestation and mystery [2],[3] for Western perceptions of Islamic teachings.

Fahri's religious attitude by promoting tolerance, friendliness, courtesy and love to help has an impact on his position as a threatened teacher. This situation emphasizes that structural power dominates social and educational practices in the state. In this context, Islamophobia is still strong in European society being made mainstream by the state. Socio-religious practices are based on the relation of perceptions, attitudes, and behavior of individuals in public spaces that aim to obtain modality so that they can occupy their social position [18]. This Ayat-Ayat Cinta movie constructs Fahri's character who has intellectual capital, wealth, and social attitudes place a central position in the battle between the suspicions of other faiths. Although Fahri had to move to Oxford University was an impressive form and the pressure of structural power. The anxiety of his friends and students is proof of the form of resistance to the policies of the university can be used as a political reference to how strong the culture of domination has taken root and become the culture of the ruling class.

\subsection{The domain of ideas and practices}

Islam as a religion and as a way of looking at the world occupies peripheral and subordinate ideas for its adherents who are constructed in the relation of the message of Islam as a religious message that commands violence, disrespect for women, and terrorists with relations between adherents of Judaism and Catholicism in London. The contestation in the film AAC (2) Islam and its adherents continues to be accused and suspected. Meanwhile, negative exclusion and negative stereotypes are continuously produced and made responsible. The factuality of the storyline of this film, evidenced in the teaching and learning process, that Fahri as a substitute teacher and students to be superior. The attitude of majority superiority is an important indicator that the dominant ideology of Edinburgh universities places Islam in a subordinate position as a process relationalconstruction [8],[19], [20],. The structural or bureaucratic domain is the dominant form of culture. Borrowing Bourdieu's concept [20], that the process of incorporation of domination takes place in the realm of ideology and politics as instruments for the preservation and socialization of ideology, namely the university and the state. The inversion mechanism through causal relations in terms of the ideology of terrorism that is developed and carried out by small groups of Muslims will affect the perception of generalization by other people, especially the perception of Jews, Christians, and Catholics.

The inversion mechanism for acts of violence, terror and other forms of violence will occur naturally by social construction. The negative construction of Jews and Catholics to Muslims is the mainstream perception of the majority. Factual evidence of negative perceptions is produced on campus, in neighbors, in a mini-market, even in a public shopping area. In this context, symbolic construction work gives birth to several different representations in the social realm.

\subsection{The hegemony and interpersonal domain}

The hegemony domain includes images, symbols, ideas, ideologies that shape social awareness. Meanwhile, the interpersonal domain includes patterns of interaction between individuals and groups. In This context, Fahri as a central figure and represented as a wise figure, generous, intelligent, polite, tolerant, friendly and all the attributes of a perfect individual ideal, but he is always faced with diverse problems from neighbors of different religions. Meanwhile, Misbah was an old friend when in Egypt was accommodated in his house and Hulusi was the driver and assistant of his household who lived in one house. While Hulya is the son of Fahri's uncle who wishes to study in Edinburg. While Catarina is a Jewish grandmother who was oppressed by her stepchildren.

Kiera is Fahri's neighbor, he always hates and is hostile to Fahri; he accused Fahri along with other Muslims as the murderer of his father who was killed in a bomb in London. In addition, Keira's younger brother Jason accused Islam of being a terrorist and he also continued to curse Fahri when he met. Baruch is the stepchild of Catarina, who has always accused Fahri and other Muslims of being terrorist accomplices or charities as fools like donkeys. The representation of antagonistic figures such as Keira, Josan, and Baruch is a social agent's behavior that cannot be separated from an idea and perspective on Islam as a religion of terror. This pattern of communication and action as proof of their construction is inseparable from the aspect of the dominance of the social structure in charge of maintaining it. For example, the use of harsh language and shouting at Muslim figures is a symbol of superiority.

When Fahri struggles with Muslims to preach and develop religious practices in a polite, friendly, caring and helpful way to different faiths. Fahri is confronted with the reality of non-Islamic societies. Muslims are accused of being a poor group and becoming a beggar society. British and Scottish daily headlines with beggar "bad face" image. Meanwhile, the beggar named Sabina, he is Aisha (Fahri's wife) disguised as Sabina. Related to media propaganda with negative stereotypes towards the face of Islam, he works hard to introduce the true messages of Islam, which is tolerant, peaceful and compassionate. Media Daily Popaganda in England and Scotland against the bad image 
[10] Noam, Chomsky, Fateful Triangle: The United States, Israel and the Palestinians. South End Press: South End Press.

[11] Inglis, Fred., "Citizenship and the Media," Eur. Rev., vol. 3, hlm. 257-268, 2001.

[12] Collins, Patrecia Hill, Black Faminist Thought: Knowledge, Conciousness, and the Politics of Empowermen. New York: Routledge Press, 2000.

[13] Bonnie Thornton Dill and Ruth Enid Zambrana, Emerging Intersections: Race, Class, and Gender in Theory, Policy, and Practice. London: Rutgers University Press, 2009.

[14] M. Hilmy, "The Political Economy of SunniShi'ah conflict in Sampang Madura," Al-Jāmi'ah J. Islam. Stud., vol. 53, hlm. . 27-51, 2015.

[15] Kikue Hamayotsu, "Conservative Turn? Religion, State and Conflict in Indonesia," Pac. Aff., vol. 87, hlm. 515-525, Des 2014.

[16] Roland Barthes, Mythology. London: Cape, 1972.

[17] Samuel P. Huntington, "The Clash of Civilization?"," Foreign Aff., hlm. 3, 1993.

[18] "https://hotair.com/archives/2018/03/04/portlandstate-university-panel-discussion-intersectionalityreligion/,.",

[19] Richard Harker, C. Mahar, dan Chris Wilkes, An Introduction to The work of Pierre Bourdieu: The Practice Theory (Habitusx Modal)+ Ranah = Praktik: Pengantar Paling Komprehensif kepada Pemikiran Boudieu. Yogyakarta: Jalasutra, n.t.

[20] Scott A. Eldridge (terakhir), Lucia GarciaCarretero, dan Marcel Broersma, "Disintermediation in social Networks: Coceptualizing Political Actors' Construction of Public on Twitter," Media Commun., vol. 7 , no. 1, hlm. 271-285.

[21] Pierre Bourdieu, La Domintion Masculine (Dominasi Maskulin). Yogyakarta: Jalasutra,2010.

[22] Sara Mills, Discourse; New critical Idiom, Routledge; 2 edition, 2004.

[7] "https://hotair.com/archives/2018/03/04/portlandstate-university-panel-discussion-intersectionalityreligion."

[8] Jamie Frueh, Political Identity and social change. Albany: State University of New York Press, 2003.

[9] Wisse, Ruth, “At Harvard, Groupthink About Islam,” Wall Str. J., Okt 2010. 